\title{
PENGARUH MODEL PEMBELAJARAN KOOPERATIF TIPE JIGSAW TERHADAP HASIL BELAJAR IPS KELAS VIII
}

\author{
Dwi Niti Wuriasih ${ }^{*}$, Haryadi², Jaryono ${ }^{3}$ \\ 1,2,3 Fakultas Ekonomi dan Bisnis, Universitas Jenderal Soedirman, Indonesia \\ *Email corresponding author: wuriasih.dwiniti@gmail.com
}

\begin{abstract}
Abstrak
Penelitian ini bertujuan untuk menguji: (1) perbedaan hasil belajar kognitif antara model pembelajaran kooperatif tipe jigsaw dengan model pembelajaran konvensional, (2) perbedaan hasil belajar afektif antara model pembelajaran kooperatif tipe jigsaw dengan model pembelajaran konvensional, (3) perbedaan psikomotor hasil belajar antara model pembelajaran kooperatif tipe jigsaw dengan model pembelajaran konvensional, (4) perbedaan hasil belajar antara model pembelajaran kooperatif tipe jigsaw dengan model pembelajaran konvensional. Penelitian ini merupakan jenis penelitian eksperimental murni dengan lokasi penelitian di SMP Negeri 2 Sumbang "Pengaruh Penerapan Model Pembelajaran Kooperatif Tipe Jigsaw terhadap Hasil Belajar Ilmu Pengetahuan Sosial Kelas VIII SMP Negeri 2 Sumbang Tahun Akademik 2018/2019 ". Hasil penelitian yaitu: (1) terdapat perbedaan hasil belajar kognitif yang signifikan antara model pembelajaran kooperatif tipe jigsaw dengan model pembelajaran konvensional sebesar 81,29 > 72,4, (2) terdapat perbedaan yang signifikan hasil belajar afektif antara model pembelajaran kooperatif tipe jigsaw dengan model pembelajaran konvensional, (3) terdapat perbedaan hasil belajar yang signifikan psikomotorik antara model pembelajaran kooperatif tipe jigsaw dengan model pembelajaran konvensional, (4) perbedaan yang signifikan hasil belajar antara model pembelajaran kooperatif tipe jigsaw dengan model pembelajaran konvensional.
\end{abstract}

Kata Kunci: Jigsaw, Pembelajaran Kooperatif, Hasil Belajar.

\begin{abstract}
This study aims to examine: (1) differences in cognitive learning outcomes between jigsaw type cooperative learning models with conventional learning models, (2) differences in affective learning outcomes between jigsaw type cooperative learning models with conventional learning models, (3) differences in psychomotor learning outcomes between jigsaw cooperative learning model with conventional learning models, (4) differences in learning outcomes between jigsaw type cooperative learning models with conventional learning models. This research is a type of pure experimental research with a research location in the form of Sumbang 2 Public Middle School "The Effect of the Application of the Jigsaw Type Cooperative Learning Model to Social Sciences Learning Outcomes of Class VIII of State Middle School 2 Contributes to the 2018/2019 Academic Year". The results of the study are: (1) there are significant differences in cognitive learning outcomes between the jigsaw type cooperative learning model with the conventional learning model of $81,29>72,4$, (2) there are significant differences in the affective learning outcomes between the jigsaw type cooperative learning model and conventional learning models, (3) there are significant differences in psychomotor learning outcomes between jigsaw cooperative learning models with conventional learning models, (4) significant differences in learning outcomes between jigsaw type cooperative learning models with conventional learning models.
\end{abstract}

Keywords: Jigsaw, Cooperative Learning, Learning Outcomes.

\section{PENDAHULUAN}

Hasil belajar merupakan salah satu indikator penilaian kualitas pendidikan yang ada di setiap lembaga pendidikan yang menyelenggarakannya. Hasil belajar yang diharapkan dalam proses belajar-mengajar yang dilakukan oleh guru sebagai pengajar dan siswa sebagai pembelajar adalah terdapatnya perubahan sikap, watak, perilaku, ketrampilan dan kemampuan 
siswa atau yang meliputi aspek kognitif, psikomotorik, dan afektif (Nana Sudjana, 2011). Pengukuran keberhasilan belajar tampak nyata dari keberhasilan siswa dalam mencapai Kriteria Ketuntasan Minimal (KKM). Upaya yang dapat dilakukan untuk mengoptimalkan hasil belajar siswa dalam setiap mata pelajaran yaitu dengan pemilihan model pembelajaran oleh guru sebagai pengajar, yang dapat mempengaruhi keefektifan dan keberhasilan pembelajaran yang terjadi di dalam kelas. Model pembelajaran merupakan salah satu faktor eksternal yang berasal dari luar diri siswa, yang mempengaruhi hasil belajar siswa yaitu dari faktor guru sebagai pengajar yang menyampaikan materi pelajaran di dalam kelas. Pemilihan model pembelajaran bagi guru perlu untuk dipertimbangkan secara tepat, sehingga ketika menyampaikan materi pelajaran di dalam kelas tidak monoton dan membosankan, dan siswa dapat turut berpatisipasi aktif, serta termotivasi untuk mengikuti pelajaran dengan ceria.

Yeti dan Diana (2009) menyatakan bahwa pembelajaran dengan menggunakan model pembelajaran kooperatif tipe jigsaw hasilnya lebih baik dalam upaya peningkatan penguasaan konsep oleh siswa. Jhonson and Jhonson dalam Teti Sobari (2006) mengungkapkan pendapat mengenai manfaat model pembelajaran kooperatif tipe Jigsaw yaitu dapat meningkatkan hasil belajar; meningkatakan daya ingat; dapat digunakan untuk mencapai tarap penalaran tingkat tinggi; mendorong tumbuhnya motivasi intrinsik (kesadaran individu); membantu meningkatkan hubungan antar manusia yang heterogen; meningkatkan sikap yang positif terhadap sekolah; meningkatkan sikap yang positif terhadap guru; meningkatkan perilaku penyesuaian sosial yang positif; serta meningkatkan keterampilan hidup gotong royong.

Berdasarkan pengamatan yang dilakukan pada SMP N 2 SUMBANG, Pembelajaran Ilmu Pengetahuan Sosial (IPS) yang dilaksanakan oleh guru di SMP N 2 SUMBANG kepada siswa belum menunjukan interaksi yang aktif, belum adanya kreativitas guru dalam mengelola kelas terbukti dengan penggunaan metode pembelajaran yang masih konvensional yaitu menggunakan metode ceramah menyebabkan suasana kelas menjadi kurang partisipatif karena pemusatan kelas hanya kepada guru (teacher center).

Penggunaan model pembelajaran dengan ceramah mengakibatkan siswa tidak mampu berkembang secara maksimal, karena tidak diberikannya ruang bagi siswa agar dapat secara kritis berpikir untuk memahami materi dan kesempatan lebih untuk menyampaikan pendapatnya di dalam kelas. Kebanyakan siswa di dalam kelas ketika pembelajaran Ilmu Pengetahuan Sosial (IPS) dengan model pembelajaran ceramah, siswa hanya berkesempatan untuk mendengarkan guru yang menyampaikan materi, dan kurangnya partisipai siswa dalam bertanya atau tergolong masih rendah.

Permasalahan yang ada tersebut mengakibatkan siswa kurang dapat memahami pelajaran Ilmu Pengetahuan Sosial (IPS) secara maksimal. Berdasarkan data yang diperoleh dari hasil nilai Ujian Tengah Semester (UTS) mata pelajaran Ilmu Pengetahuan Sosial (IPS) kelas VIII 
SMP N 2 Sumbang, menunjukan bahwa masih banyak siswa untuk mencapai nilai Kriteria Ketuntasan Minimal (KKM) yang belum berhasil atau belum tuntas, hal terebut dapat terlihat dari tabel 1 berikut ini:

Tabel 1. Hasil Belajar UTS IPS Siswa Kelas VIII SMP N 2 SUMBANG Tahun Pelajaran 2018/2019

\begin{tabular}{ccccc}
\hline Kelas & KKM & Jumlah Siswa & Belum Tuntas & Nilai Rata-rata \\
\hline VIII A & 72 & 32 Siswa & $59 \%$ & 68,22 \\
VIII B & 72 & 32 Siswa & $94 \%$ & 55,34 \\
VIII C & 72 & 33 Siswa & $69 \%$ & 66,46 \\
VIII D & 72 & 32 Siswa & $87,5 \%$ & 57 \\
VIII E & 72 & 32 Siswa & $16,6 \%$ & 80,72 \\
VIII F & 72 & 32 Siswa & $46,9 \%$ & 70,89 \\
\hline
\end{tabular}

Sumber: Dokumentasi Guru IPS

Berdasarkan pada data hasil UTS siswa dalam tabel 1 menunjukan bahwa masih banyaknya siswa yang belum memperoleh hasil belajar Ilmu Pengetahuan Sosial (IPS) yang baik. Masih banyak siswa yang belum tuntas dalam mengikuti pembelajaran Ilmu Pengetahuan Sosial (IPS) karena belum dapat mencapai Kriteria Ketuntasan Minimal (KKM) yang telah ditetapan oleh guru, dibuktikan dengan perolehan nilai siswa dalam Ujian Tengah Semester (UTS) mata pelajaran Ilmu Pengetahuan Sosial (IPS) yang masih dibawah standar Kriteria Ketuntasan Minimal (KKM) yaitu 72. Dimana sebesar 61 \% dari 193 jumlah siswa kelas VIII dinyatakan belum tuntas dalam mengikuti pembelajaran mata pelajaran Ilmu Pengetahuan Sosial (IPS).

Berdasarkan permasalahan di atas, maka tujuan penelitian ini antara lain untuk: (1) mengetahui apakah terdapat perbedaan hasil belajar kognitif antara model pembelajaran kooperatif tipe Jigsaw dengan model pembelajaran konvensional; (2) mengetahui apakah terdapat perbedaan hasil belajar afektif antara model pembelajaran kooperatif tipe Jigsaw dengan model pembelajaran konvensional; (3) mengetahui apakah terdapat perbedaan hasil belajar psikomotorik antara model pembelajaran kooperatif tipe Jigsaw dengan model pembelajaran konvensional; (4) mengetahui apakah terdapat perbedaan hasil belajar antara model pembelajaran koopeartif tipe Jigsaw dengan model pembelajaran konvensional.

\section{TINJAUAN PUSTAKA DAN PERUMUSAN HIPOTESIS}

Hasil belajar tidak terlepas dari proses belajar yang dilakukannya. Slameto (2010) menjelaskan bahwa pengertian belajar adalah proses yang dilakukan seseorang untuk mendapatkan perubahan tingkah laku baru secara menyeluruh, dan merupakan hasil dari pengalaman yang dilakukannya sendiri dalam interaksi dengan lingkungan disekitarnya. Hasil belajar itu sendiri merupakan hasil dari kegiatan belajar seseorang berupa perubahan yang menetap dalam dirinya. Perubahan perilaku yang didapatkan merupakan perolehan yang 
menjadi hasil belajar, tidak hanya hasil belajar berupa aspek kognitif (pengetahuan) yang diperoleh peserta didik. (Purwanto, 2011). Hasil belajar yaitu perubahan tingkah laku sebagai hasil belajar yang mencakup ranah kognitif, afektif, dan psikomotor (Nana Sudjana, 2011).

Menurut Sudjana (2005), Hasil Belajar yang dicapai siswa dapat dipengaruhi oleh dua faktor, yaitu faktor dari dalam diri siswa (internal) dan faktor dari luar diri siswa (eksternal). Faktor- faktor tersebut dapat diuraikan sebagai berikut: (1) Faktor Internal (faktor yang berasal dari dalam diri siswa), meliputi: kemampuan yang dimilikiny seniri; minat dan perhatian yang dicurahkan; motivasi dalam belajar; konsep diri; sikap dan kebiasaan belajar; status sosial ekonomi; ketekunan; fisik dan psikis. (2) Faktor Eksternal (faktor yang berasal dari luar diri siswa), yaitu lingkungan dan kualitas pengajaran merupakan faktor yang paling dominan. Kualitas pengajaran merupakan profesionalisme yang dimiliki oleh guru, berupa kemampuan dasar guru baik di bidang kognitif (intelektual), bidang sikap (afektif) dan bidang perilaku (psikomotorik).

Siswa dapat dikatakan berhasil mencapai komptensi sesuai dengan tujuan pembelajaran dapat dilakukan dengan melakukan penilaian hasil belajar siswa tersebut. Hasil belajar berkaitan erat dengan penilaian. Penilaian Guru terhadap hasil pembelajaran dilakukan dengan tujuan untuk mengukur tingkat pencapaian kompetensi siswa, sebagai bahan penyusun laporan kemajuan hasil belajar siswa, dan bahan perbaikan pada proses pembelajaran berikutnya (Rusman, 2013).

Keberhasilan proses pembelajar tidak terlepas dari peran model pembelajaran yang digunakan oleh guru dalam menyampaikan materi pelajaran kepada para siswanya. Sehingga perlu adanya kreativitas dari guru untuk mencapai tujuan setiap pembelajaran yang akan dilakukannya. Uno (2010) berpendapat bahwa model pembelajaran merupakan salah satu cara yang digunakan oleh guru dalam menjalankan fungsinya dan merupakan alat untuk mencapai tujuan pembelajaran yang dilakukannya. Sugiyanti (2009) menggolongkan model pembelajaran menjadi lima macam, yaitu sebagai berikut: (1) Model pembelajaran kontekstual (constextual teaching and learning CTL), (2) Model pembelajaran kooperatif (cooperative learning), (3) Model pembelajaran quantum (quantum learning), (4) Model pembelajaran berbasis masalah (Problem

\section{Based Learning).}

Model pembelajaran kooperatif merupakan salah satu dari model pembelajaran yang tidak hanya melibatkan siswa untuk belajar namun juga untuk bekerjasama dalam tim. Model pembelajran kooperatif tipe jigsaw sebagai jenis model pembelajaran kooperatif didalamnya terdapat kelompok asal dan kelompok ahli dalam kegiatan pembelajaran. Setiap anggota kelompok yang mendapatkan materi yang berbeda berkumpul dan berdiskusi dalam kelompok asal, baru kemudian berkumpul dan berdiskusi di dalam kelompok baru yang mendapatkan materi yang sama disebut sebagai kelompok ahli. Masing-masing kelompok ahli bertanggung 
jawab untuk sebuah materi atau pokok bahasan. Setelah kelompok ahli selesai mempelajari satu topik materi keahliannya, masing-masing siswa kembali ke kelompok asal mereka untuk mengajarkan materi keahliannya kepada teman dalam satu kelompok dalam bentuk diskusi, (Isjoni, 2010).

Rengga dan Herman (2012) menunjukan bahwasannya penggunaan model pembelajaran kooperatif tipe jigsaw dapat memberikan hasil belajar yang baik pada ranah kognitif, afektif, dan psikomotorik siswa. Penelitian Jhonson and Jhonson (dalam Teti Sobari 2006) tentang pembelajaran kooperatif tipe jigsaw dimana interaksi kooperatif memiliki pengaruh yang positif terhadap perkembangan anak, yaitu: meningkatkan hasil belajar dan daya ingat anak, mendapatkan penalaran tingkat tinggi, mendorong tumbuhnya motivasi intrinsik (kesadaran individu), meningkatkan hubungan antarmanusia yang beragam, meningkatkan sikap positif anak terhadap sekolah dan guru, meningkatkan perilaku penyesuaian sosial positif, dan meningkatkan keterampilan hidup gotong royong.

Berdasarkan teori dan perumusan masalah yang ada, maka dapat di rumuskan hipotesis pada penelitian ini yaitu:

H1: Terdapat perbedaan hasil belajar kognitif antara model pembelajaran kooperatif tipe Jigsaw dengan model pembelajaran kovensional,

H2: Terdapat perbedaan hasil belajar afektif antara model pembelajaran kooperatif tipe Jigsaw dengan model pembelajaran kovensional,

H3: Terdapat perbedaan hasil belajar psikomotorik antara model pembelajaran kooperatif tipe Jigsaw dengan model pembelajaran kovensional,

H4: Terdapat perbedaan hasil belajar kognitif,afektif, dan psikomotorik antara model pembelajaran kooperatif tipe Jigsaw dengan model pembelajaran konvensional.

\section{METODE PENELITIAN}

\section{Rancangan penelitian}

Penelitian ini termasuk kedalam jenis penelitian eksperimen murni (true experiment). Penelitian eksperimen murni dilakukan dengan tujuan untuk menguji variabel bebas dan variabel terikat terhadap sampel kelompok eksperimen dan kelompok kontrol (Arifin, 2012). Penelitian eksperimen murni (true experiment) tediri dari kelompok kontrol dan kelompok eksperimen yang diambil secara acak atau random (Sugiyono, 2009). Teknik sampling yang digunakan adalah simple random sampling, dimana anggota dalam populasi setiap kelompoknya memiliki peluang yang sama untuk dijadikan sampel (Suliyanto, 2018). Desain penelitian yang digunakan dalam penelitian eksperimen ini yaitu Pretest-Posttest Only Design, yaitu desain eksperimen dimana dua kelompok yang dipilih secara acak diberikan pretest untuk 
mengukur kemampuan awal siswa apakah terdapat perbedaan antara kelompok eksperimen dan kelompok kontrol (Sugiyono, 2015).

Kelompok sampel yang diberi perlakuan disebut dengan Kelompok eksperimen , sementara kelompok sampel yang tidak diberi perlakuan disebut dengan kelompok kontrol. Pada kelompok kontrol dan kelompok eksperimen tersebut diberikan post test (tesnya sama) kemudian diberikan perlakuan khusus untuk kelompok eksperimen berupa penerapan model pembelajaran kooperatif tipe jigsaw. Hasil posttest antara kelas kontrol dan kelas eksperimen kemudian dibandingkan atau diuji perbedaanya.

Menurut Arifin (2012) desain penelitian eksperimen terlihat dari tabel 6 berikut ini:

Tabel 2. Desain Penelitian Pretest Posttest Only Design

\begin{tabular}{cccc}
\hline Kelompok & Pre Test & Perlakuan & Post Test \\
\hline Eksperimen & $\mathrm{O}_{1}$ & $\mathrm{X}$ & $\mathrm{O}_{2}$ \\
Kontrol & $\mathrm{O}_{1}$ & - & $\mathrm{O}_{2}$ \\
\hline
\end{tabular}

Keterangan :

$\mathrm{O}_{1}$ : Hasil pre test

$\mathrm{X}$ : Pemberian perlakuan pembelajaran dengan menggunakan model kooperatif tipe jigsaw

$\mathrm{O}_{2}$ : Hasil post test

\section{Populasi dan sampel}

Populasi dalam penelitian ini yaitu siswa kelas VIII SMP N 2 Sumbang yang berjumlah 193 siswa terdiri dari kelas VIIIA - VIIIF. Sampel dalam penelitian ini diambil dengan menggunakan teknik simple random sampling terhadap kelas kontrol dan kelas eksperimen. Berdasarkan tabel 1 dan teknik sampling yang digunakan yaitu simple random sampling, tahap pertama peneliti akan mengambil dua kelas secara acak dengan pengundian setelah terpilih dua kelas akan dilakukan pengundian kembali untuk menentukan mana sebagai kelas kontrol dan mana sebagai kelas eksperimen.

\section{Teknik pengumpulan dan pengembangan instrument}

Peneliti dalam mengumpulkan data untuk penelitian menggunakan teknik tes, angket dan dokumentasi. Teknik tes digunakan untuk mengetahui data tentang hasil belajar aspek kognitif. Kuesioner/Angket dalam penelitian ini digunakan untuk membantu mendapatkan jawaban mengenai pengaruh penerapan model pembelajaran terhadap hasil belajar aspek afketif dan psikomotorik. Teknik dokumentasi diperlukan untuk mengetahui daftar nama siswa yang menjadi responden dalam penelitian, hasil belajar limu Pengetahuan Sosial (IPS) dan uji coba instrumen. 


\section{Analisis Data}

Korelasi product moment merupakan salah satu teknik analisis yang dapat dipergunakan untuk menguji tingkat validitas soal dan butir pertanyaan instrumen penelitian kuesioner / angket yang akan diujikan. Sugiyono (2012) menyatakan bahwa pengujian reliabilitas suatu instrumen dapat dilakukan secara internal dan eksternal. Secara internal pengujian reliabilitas instrumen dapat dilakukan dengan melakukan analisis konsistensi butir-butir instrumen menggunakan teknik tertentu. Teknik Cronbach Alpha dapat digunakan untuk menguji tingkat reliabilitas instrumen butir soal dan pertanyaan kuesioner / angket. Instrumen butir soal dalam penelitian yang akan digunakan untuk mengukur hasil belajar aspek kognitif siswa berupa teknik tes dengan jenis tes yang digunakan yaitu soal pilihan ganda, sebelumnya perlu terlebih dahulu dilakukukan pengujian tingkat kesukaran soalnya. Soal yang baik adalah soal yang memiliki tingkat kesukaran tidak terlalu mudah dan soal yang tidak terlalu sukar (sulit). Semakin mudah suatu soal, maka akan semakin besar indeks tingkat kesukarannya dan begitu pula sebaliknya.

Uji kesamaan rata- rata digunakan untuk mengetahui seberapa jauh kemampuan awal yang dimiliki oleh siswa pada kelompok kontrol dan kelompok eksperimen. Penelitian eksperimen dapat dilaksanakan apabila kelompok kontrol dan kelompok eksperimen memiliki karakteristik yang sama, hal ini dapat diukur dari uji kesamaan rata-rata untuk mengukur kemampuan awal siswa. Untuk menilai data skor tes kelompok kontrol dan kelompok eksperimen berberdistribusi normal atau tidak, maka dilakukan pengujian normalitas. Uji normalitas yang digunakan peneliti dalam penelitian ini adalah menggunakan uji Chi-Square. Analisis data yang digunakan dalam desain penelitian eksperimen ini yaitu menggunakan t-test berupa independent sample test. Pengujian independent sample test digunakan untuk menguji dua kelompok data dari kelompok sampel yang berbeda (Mulyatiningsih,2014). Analisis uji t ini dilakukan untuk mengetahui kesimpulan dari penelitian eksperimen yang dilakukan. Pengujian hipotesis dalam penelitian eksperimen ini dilakukan dengan membandingkan hasil dari kelompok kontrol dengan kelompok eksperimen, sehingga digunakan $t$ test sampel related (Sugiyono, 2012)

\section{HASIL DAN PEMBAHASAN}

Pengukuran kesamaan rata-rata pada sampel dilakukan dengan pemberian Pretest sebelum pembelajaran dimulai pada kelas kontrol dan kelas eksperimen. Pengujian kesamaan rata-rata kemampuan awal juga dilakukan dengan menggunakan bantuan program SPSS 16 for Windows melalui alat analisis independent sample test yang memiliki hasil Sig sebesar 0,655 > 0,005 yang berarti tidak terdapat perbedaan hasil pretest yang signifikan antara kelas 
eksperimen dan kelas kontrol, dan artinya kelas kontrol dan kelas eksperimen penelitian memiliki karakteristik yang sama, karena rata-rata kemampuannya sama menandakan penelitian eksperimen ini dapat dilakukan.

Setelah dilakukan pengukuran kemampuan awal anggota sampel dengan melakukan pretest, langkah selanjutnya yaitu mengukur distribusi skor tes apakah berdistribusi normal atau tidak normal. Penelitian dapat dilakukan apabila memiliki distribusi data yang normal. Uji normalitas dilakukan dengan menggunakan uji chi square yaitu digunakan untuk penelitian komparatif. didapatkan bahwa nilai Chi Square hitung antara kelas kontrol dan kelas eksperimen kurang dari nilai Chi Square tabel, hal ini menunjukan bahwa skor data penelitian berdistribusi normal. Sehingga dapat dilanjutkan dengan pengujian hipotesis menggunakan $t$ test.

Selanjutnya yaitu pengujian hipotesis. Pada hipotesis pertama yang merupakan perbandingan antara hasil belajar aspek kognitif antara kelas kontrol dan kelas eksperimen atau untuk menjawab hipotesis pertama. Diketahui nilai Sig 0,00 $\leq 0,05$ maka hipotesis dapat diterima, yang berarti terdapat perbedaan signifikan hasil belajar kognitif antara model pembelajaran kooperatif tipe jigsaw dengan model pembelajaran konvensional. Peningkatan hasil belajar dapat diupayakan lebih tinggi lagi apabila guru lebih menyesuaikan antara banyaknya materi dengan waktu pembelajaran yang tersedia. Pada kelas kontrol peneliti tidak memberikan perlakuan, dimana dalam pembelajaran menggunakan model pembelajaran konvensional atau ceramah, sehingga siswa merasa bosan, dan ada siswa yang tertidur serta kurang fokus dalam pembelajaran. Sedangkan dalam kelas eksperimen peneliti memberikan perlakuan dengan pembelajaran menggunakan model pembelajaran kooperatif tipe jigsaw, dan siswa merasa antusias dan aktif.

Pada hipotesis kedua yang merupakan perbandingan antara hasil belajar aspek afektif antara kelas kontrol dan kelas eksperimen atau untuk menjawab hipotesis kedua. Diketahui nilai Sig 0,005 $\leq$ 0,05 maka hipotesis dapat diterima, yang berarti terdapat perbedaan signifikan hasil belajar afektif antara model pembelajaran kooperatif tipe jigsaw dengan model pembelajaran konvensional. Hasil belajar dapat meningkat apabila siswa memiliki sikap disiplin, kejujuran, gotong royong, tanggungjawab, dan sopan santun yang tinggi. Pengukuran dengan menggunakan kuesioner yang dibagikan kepada siswa baik kelas kontrol dan eksperimen setelah dilakukan pembelajaran. baru sebanyak $80 \%$ siswa kelas kontrol sedangkan $100 \%$ atau seluruh siswa kelas eksperimen dinilai telah berhasil mencapai hasil belajar afektif yang didasarkan kepada 4 aspek penilaian yaitu penilaian sikap disiplin, kejujuran, gotong royong, tanggungjawab, dan sopan santun sebagai akibat dari hasil proses belajar yang dilakukan oleh siswa (Sudjana,2004). Penilaian yang tinggi diperoleh kelas eksperimen yaitu pada sikap displin siswa yang lebih tinggi dengan mencatat materi yang di diskusikan bersama 
teman, sikap tanggungjwab dengan berusaha memperdalam materi dari buku, sikap gotong royong dengan berusaha mendorong teman untuk aktif dalam kelompok dibandingkan pada penilaian sikap afektif kelas kontrol yang lebih banyak pasif dan individualis.

Pada hipotesis ketiga yang merupakan perbandingan antara hasil belajar aspek psikomotorik antara kelas kontrol dan kelas eksperimen atau untuk menjawab hipotesis ketiga. Diketahui nilai Sig 0,001 $\leq$ 0,05 maka hipotesis dapat diterima, yang berarti terdapat perbedaan signifikan hasil belajar psikomotorik antara model pembelajaran kooperatif tipe jigsaw dengan model pembelajaran konvensional. Pembentukan kelompok pada model pembelajaran kooperatif tipe jigsaw lebih banyak meningkatkan ketrampilan siswa dalam memahami perintah (Sudjana, 2004). Penggunaan instrumen yang mengukur hasil belajar psikomotorik berupa kemampuan siswa dalam mengerjakan tugas dengan cepat serta mampu membaca gambar dan simbol (perintah guru) berupa kuesioner menunjukan baru sebanyak 76\% siswa kelas kontrol dan sebanyak $100 \%$ atau seluruh siswa kelas eksperimen yang dinyatakan berhasil memiliki nilai hasil belajar psikomotorik yang bagus. Pembentukan kelompok dalam kelas eksperimen membantu merangsang siswa untuk lebih meningkatkan kemampuan memahami perintah guru serta kemampuan kerjasama dalam kelompok.

Pada hipotesis ke empat yang merupakan perbandingan antara hasil belajar aspek kognitif, afektif, dan psikomotorik antara kelas kontrol dan kelas eksperimen atau untuk menjawab hipotesis keempat. Diketahui nilai Sig 0,000 $\leq 0,05$ maka hipotesis dapat diterima, yang berarti terdapat perbedaan signifikan hasil belajar antara model pembelajaran kooperatif tipe jigsaw dengan model pembelajaran konvensional. Hasil belajar itu sendiri pada hakikatnya wujud dari adanya perubahan pada aspek kognitif, afektiff, dan psikomotorik (Sudjana,2004). Pengukuran hipotesis ini dilakukan dengan menggabungkan nilai perolehan pada aspek kognitif dengan aspek afektif dan psikomotorik antara kelas kontrol dengan kelas eksperimen. Kelas kontrol memiliki nilai 9,30 dan 10,40 untuk kelas eksperimen dari skala 12. Peningkatan nilai pada setiap aspek dapat lebih dimaksimalkan dengan adanya kemampuan guru dalam penggunaan model pembelajaran, pengelolaan kelas dalam menciptakan situasi pembelajaran yang aktif dan kondusif, serta peningkatan kemampuan berpikir kritis siswa dan tidak lemah dalam upaya peningkatan sikap disiplin, tanggungjawab, kejujuran, gotong royong dan sopan santun terhadap sesama.

\section{KESIMPULAN}

Terdapat perbedaan yang signifikan hasil belajar kognitif berupa pengetahuan, pemahaman, penerapan, dan analisis terhadap pelajaran berupa posttest antara model pembelajaran kooperatif tipe jigsaw dengan model pembelajaran konvensional; Terdapat 
perbedaan yang signifikan hasil belajar afektif berupa sikap displin, tanggungjawab, sopan santun, gotong royong, dan jujur dalam mengikuti pembelajaran antara model pembelajaran kooperatif tipe jigsaw dengan model pembelajaran konvensional; Terdapat perbedaan yang signifikan hasil belajar psikomotorik berupa sikap kerja siswa, kecepatan siswa dalam mengerjakan tugas, dan kemampuan siswa dalam membaca gambar dan simnol antara model pembelajaran kooperatif tipe jigsaw dengan model pembelajaran konvensional; Terdapat perbedaan yang signifikan hasil belajar antara model pembelajaran kooperatif tipe jigsaw dengan model pembelajaran konvensional.

\section{DAFTAR PUSTAKA}

Agustin, Rengga Rea dan Hermin Budjiningarti. 2012. Penerapan Model Pembelajaran Kooperatif Tipe Jigsaw dengan Kegiatan Praktikum di Laboratorium untuk Meningkatkan Hasil Belajar Siswa Pada Materi Gerak Kelas VII Di SMP Negeri 2 Menganti. Jurnal Inovasi Pendidikan Fisika. Vol 1. No 1. Hal. 234-245.

Uno, Hamzah B. 2010. Teori motivasi dan pengukurannya. Jakarta: PT Bumi Aksara.

Isjoni. 2010. Pembelajaran Kooperalif. Yogyakarta: Pustaka Pelajar.

Purwanto. 2011. Evaluasi Hasil Belajar. Yogyakarta: Pustaka Belajar.

Rusman. 2013. Model-model Pembelajaran. Jakarta: Rajawali Pers.

Sudjana, Nana. 2004. Dasar-dasar Proses Belajar Mengajar. Bandung: Sinar Baru Algesindo. 2005. Dasar-dasar Proses Belajar Mengajar. Bandung: Sinar Baru Algesindo. 2011. Penilaian Hasil Proses Belajar Mengajar. Bandung: PT Remaja Rosydakarya.

Sugiyono. 2009. Metode Penelitian Bisnis. Bandung: Alfabeta.

2012. Metode Penelitian Kuantitatif Kualitatif Dan R\&D. Bandung: Alfabeta. 2015. Metode Penelitian Kuantitatif Kualitatif Dan R\&D. Bandung: Alfabeta.

Suliyanto. 2018. Metode Penelitian Bisnis: Untuk Skripsi, Tesis, dan Disertasi. Yogyakarta: CV.Andi Offset.

Slameto. 2010. Belajar dan Faktor-faktor yang Mempengaruhinya. Jakarta: Rineka Cipta.

Teti Sobari. 2006. Prosedur Penelitian Suatu Pendekatan Praktik. Jakarta: Rineka Cipta. 